\title{
Pencarian Lokasi Tempat Penyewaan Mobil Daerah Kota Pangkalpinang Berbasis Sistem Informasi Geografis
}

\author{
Wirriyawan Azzaki1,*, Delpiah Wayuningsih² \\ 1,2Program Studi Teknik Informatika STMIK Atma Luhur Pangkalpinang \\ (coresponding author) ${ }^{1}$ wirriyawanazzakijr11@gmail.com *,2delphibabel@atmaluhur.ac.id
}

\begin{abstract}
In general, the transport easier for people to help drive the take somewhere in the heading, with high mobility, a little time transport becomes an important part in supporting the speed and efficiency of work in the community, to support community facilities require that a rental car right place. But there are still many people who still do not know the location of car rental places scattered in the Region Pangkalpinang. The research objective is to provide facilities for the comfort of the car in Pangkalpinang tenants in finding information about the car rental place, making the application of geographic information system can provide information on the location of the car rental place using media websites; the study was conducted using a waterfall. This research results in the form of WebGIS, the location where a rental car will be displayed as detailed as possible in a web interface that allows the public
\end{abstract}

Key Word: Geographic Information System, Rental Card, Pangkalpinang, Location Search, WebGIS.

Abstrak - Secara umum transportasi memudahkan masyarakat untuk membantu perjalanan dalam menempuh suatu tempat yang di tuju, dengan mobilitas yang tinggi, waktu yang sedikit transportasi menjadi bagian penting dalam menunjang kecepatan dan efisiensi kerja pada masyarakat, untuk mendukung fasilitas masyarakat membutuhkan yang menyediakan mobil sewaan tempat yang tepat. Namun masih ada banyak orang yang masih belum tahu lokasi tempat penyewaan mobil yang tersebar di Daerah Pangkalpinang. Tujuan penelitian ini untuk memberikan fasilitas mobil untuk kenyamanan penyewa di Pangkalpinang dalam mencari informasi tempat penyewaan mobil, dengan membuat aplikasi sistem informasi geografis dapat memberikan informasi tentang lokasi tempat penyewaan mobil menggunakan media website, penelitian ini dilakukan dengan menggunakan waterfall. hasil penelitian ini dalam bentuk WebGIS, lokasi dimana mobil sewaan akan ditampilkan sedetail mungkin dalam antarmuka web yang memudahkan masyarakat.

Kata Kunci- Sistem Informasi Geografis, penyewaan mobil, Pangkalpinang, pencarian lokasi, WebGIS.

\section{PENDAHULUAN}

Perkembangan teknologi di era globalisasi saat ini berlangsung sangat cepat. Teknologi informasi sudah menjadi hal yang sangat lumrah dan sebuah keharusan dalam segala aspek kehidupan. Tak hanya itu, saat ini teknologi informasi bahkan telah menjadi tulang punggung kehidupan manusia dalam penyediaan dan pemberian informasi. Keberadaan sebuah informasi yang realtime, cepat, dan akurat menjadi hal yang sangat penting bagi kelangsungan hidup manusia saat ini. Data dan informasi yang diperlukan tentu harus mudah diakses dengan efektif dan efisien oleh berbagai pihak yang berkepentingan. Seperti halnya Sistem Informasi Geografis (SIG) yang menjadi salah satu penyampaian informasi yang mudah diakses dan lebih efisien dalam hal penyampaian informasi.

Sistem Informasi Geografis (SIG) atau juga dikenal Geographic Information Sistem (GIS) akhir-akhir ini mengalami perkembangan yang berarti seiring kemajuan teknologi informasi. SIG merupakan sistem informasi berbasis komputer yang menggabungkan antara unsur peta (geografis) dan informasinya tentang peta tersebut (data atribut) yang dirancang untuk mendapatkan, mengolah, memanipulasi, analisa, memperagakan dan menampilkan data spasial untuk menyelesaikan perencanaan, mengolah dan meneliti permasalahan. Pengguanan data geografis ini dapat digunakan untuk mengatasi masalah di segala bidang, dalam bidang transportasi SIG dapat digunakan untuk mengetahui dimana letak penyebaran transportasi itu berada.

Pada sektor transportasi umum di daerah Pangkalpinang Kepulauan Bangka Belitung sangat bervariasi seperti halnya di kota-kota besar lainnya seperti angkutan kota, dan taxi untuk transportasi pribadi biasanya masyarakat daerah pangkalpinang menggunakan motor dan mobil.

Secara umum transportasi memudahkan masyarakat untuk membantu perjalanan dalam menempuh suatu tempat yang di tuju, dengan mobilitas yang tinggi, waktu yang sedikit transportasi menjadi bagian penting dalam menunjang 
kecepatan dan efisiensi kerja pada masyarakat, tak jarang banyak orang memanfaatkan kendaraan darat sebagai angkutan paling digemari, mobil contohnya, selain dapat digunakan sesuka hati dimana akan beristirahat, juga dirasa cukup cepat sebagai angkutan yang dapat menyelesaikan mobilitas tinggi dibandingkan menggunakan angkutan kota atau taxi. Namun, bagi mereka yang tak mampu memiliki kendaraan pribadi, juga tak jarang mereka memanfaatkan penyewaan mobil sebagai pra sarana untuk menggunakan kendaraan darat.

Penyewaan mobil merupakan salah satu pra sarana untuk menunjang kebutuhan masyarakat kota pangkalpinang, khususnya masyarakat kota pangkalpinang yang ingin berlibur bersama keluarganya namun tak banyak masyarakat kota pangkalpinang yang tahu informasi tentang perusahaan penyewaan mobil dikarenakan informasi tersebar kurang efisien dengan cara menyebarkan kartu nama tempat usaha untuk itu diperlukan suatu metode penyajian informasi penyebaran perusahaan penyewaan mobil yang baik dan dapat menampilkan lokasi tempat perusahaan serta informasi yang berkaitan dengan penyewaan mobil, agar layanan jasa penyewaan tersebut berjalan secara efektif maka perlu dilakukan kerja sama dengan instansi pemerintahan yaitu Dinas Perindustrian, Perdagangan, Koperasi dan Usaha Mikro Kecil Menengah (Disperindagkop dan UMKM) yang mengelola layanan jasa dan usaha mikro dengan memberikan tempat lokasi dan informasi serta fasilitas yang diberikan. Melihat dari kenyataan tersebut, maka akan dilakukan penelitian dengan judul "Aplikasi Sistem Informasi Geografis Lokasi Tempat Penyewaan Mobil Daerah Kota Pangkalpinang Berbasis Web" Sistem Informasi Geografis ini selanjutnya disebut SIG dapat mengatasi masalah tersebut dengan cara menampilkan lokasi penyewaan mobil di kota pangkalpinang berikut dengan informasi yang berkaitan. SIG tersebut akan ditampilkan dalam bentuk informasi berbasis web, sehinga dapat dengan mudah diakses oleh masyarakat melalui internet.

Ada beberapa penelitian yang terkait dengan sistem informasi geografis. Hasil penelitian dari Danny Manongga dkk yang berjudul "sistem informasi geografis untuk perjalanan wisata di kota Semarang" yaitu SIG dapat digunakan untuk mendukung perjalanan wisata di kota Semarang, dimana SIG dapat memberikan informasi langsung kepada user mengenai lokasi dari sarana pariwisata dan fasilitas pendukung yang ada. Perancangan dan implementasi dari SIG menghasilkan beberapa fungsi yang dapat digunakan oleh user yaitu fungsi untuk mencari lokasi jalan atau suatu tempat, fungsi untuk melihat informasi detail dari hasil pencarian tersebut, fungsi untuk melihat lokasi tempat terdekat, fungsi untuk mengukur jarak dan fungsi untuk melihat informasi detail mengenai sarana pariwisata yang ada di Kota Semarang.

\section{URAIAN PENELITIAN}

\section{A. $\quad$ Sistem Informasi Geografis (SIG)}

Indarto (2013:4) menyatakan, bahwa pada prinsipnya SIG mempunyai 3 komponen utama yakni: sistem komputer, data dan pengguna (user). Jadi GIS merupakan suatu kesatuan sistem termasuk: Perangkat keras (hardware), data, perangkat lunak (software) dan pengguna yang mengaplikasikan SIG untuk menyelesaikan suatu permasalahan dalam bidang tertentu.

Tabel 1. Fungsi dan Komponen Hardware/Software

\begin{tabular}{|c|c|c|c|c|}
\hline \multirow{2}{*}{ No } & \multicolumn{2}{|c|}{ Hardware } & \multicolumn{2}{|r|}{ Software } \\
\hline & Komponen & Fungsi & Fungsi & Operasi yang dilakukan \\
\hline 1 & $\begin{array}{l}\text { Scanner, keyboard, } \\
\text { digitizer, kamera } \\
\text { digital, video }\end{array}$ & Input data & $\begin{array}{l}\text { Masukkan dan } \\
\text { pra-pengolahan } \\
\text { data }\end{array}$ & $\begin{array}{l}\text { Digitasi, editing, pembuatan } \\
\text { topologi, sistem proyeksi, } \\
\text { konversi format data, pelabelan } \\
\text { dan pemberian atribut. }\end{array}$ \\
\hline 2 & $\begin{array}{l}\text { Peta analog / citra } \\
\text { satelit/ peta digital }\end{array}$ & $\begin{array}{l}\text { Sumber data } \\
\text { spasial }\end{array}$ & $\begin{array}{l}\text { Manajemen } \\
\text { database dan } \\
\text { query }\end{array}$ & $\begin{array}{l}\text { Pengarsipan data, pencarian } \\
\text { (query), transfer data, pemodelan } \\
\text { database (relasi, obyek oriented, } \\
\text { network modeling) }\end{array}$ \\
\hline 3 & Digitizer & $\begin{array}{l}\text { Digitalisasi peta } \\
\text { analog ke digital }\end{array}$ & $\begin{array}{l}\text { Pengukuran dan } \\
\text { analisa spasial }\end{array}$ & $\begin{array}{l}\text { Operasi pengukuran, pembuatan } \\
\text { buffer zone, clip, intersect, } \\
\text { thematic map, dll }\end{array}$ \\
\hline 4 & CPU/PC/Laptop & $\begin{array}{l}\text { Pengolahan } \\
\text { Informasi }\end{array}$ & \multirow[t]{4}{*}{$\begin{array}{l}\text { Output dan } \\
\text { visualisasi }\end{array}$} & \multirow[t]{4}{*}{$\begin{array}{l}\text { Transformasi skala, printing, } \\
\text { layout, 3D, dll. }\end{array}$} \\
\hline 5 & Monitor, layar, screen & Visualisasi & & \\
\hline 6 & Plotter, printer & Pencetakan & & \\
\hline 7 & Network & $\begin{array}{l}\text { Komunikasi antar } \\
\text { komponen }\end{array}$ & & \\
\hline
\end{tabular}

Sumber: Indarto (2013) 


\section{1) Sistem Komputer}

Sistem Komputer untuk SIG terdiri dri: perangkat keras (Hardware) dan perangkat lunak (Software). Ada berbagai macam perangkat keras dan perangkat lunak digunakan untuk SIG, yang dapat dilihat pada Tabel 1.

2) Data Geospatial

Geospasial terdiri dari dua komponen, yaitu: komponen grafis (data geometris) dan data atribut.

a. Komponen Grafis

Terdiri dari data-data yang menggambarkan suatu fitur atau penampakan yang ada di permukaan bumi, misalnya: jalan, sungai, peruntukan, dan sebagainya. Komponen grafis dapat berupa: titik (point), garis (line/polyline) dan poligon (polygone) dalam format vektor maupun raster, yang melambangkan topologi geometris (ukuran, bentuk, posisi dan orientasi) suatu obyek atau fitur yang digambarkan.

b. Data Atribut

Sumber data untuk SIG dapat berasal dari: digitalisasi peta, foto udara, citra satelit, tabel statistik, laporan, peta analog, dan peta digital. Obyek atau fitur alam di permukaan bumi dilambangkan ke dalam suatu model data. Model data untuk SIG dapat berupa: vektor, raster atau TIN (triangular irregular network). Data untuk SIG disebut juga data geospasial.

c. Pengguna SIG

Pada prinsipnya hampir semua bidang kehidupan membutuhkan dukungan SIG untuk membantu menyelesaikan permasalahan. Pengguna (user) akan menentukan informasi apa yang dibutuhkan dari suatu GIS. Menentukan standar yang dibutuhkan. Memilih cara memperbaharui data yang paling efisien dan menganalisa output SIG dan merencanakan implementasi ke suatu permasalahan.

B. Analisis

1) Activity Diagram

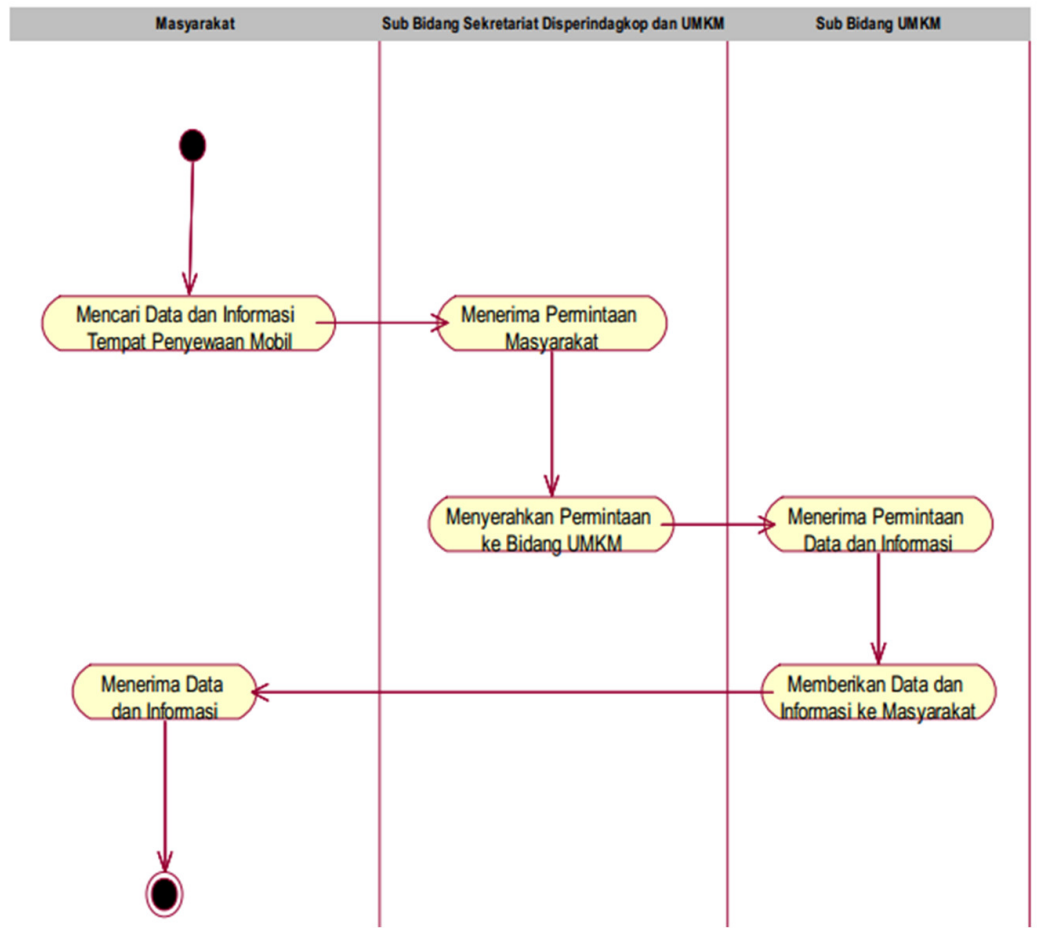

Gambar 1. Activity Diagram Masyaraka Mendapatkan Informasi 


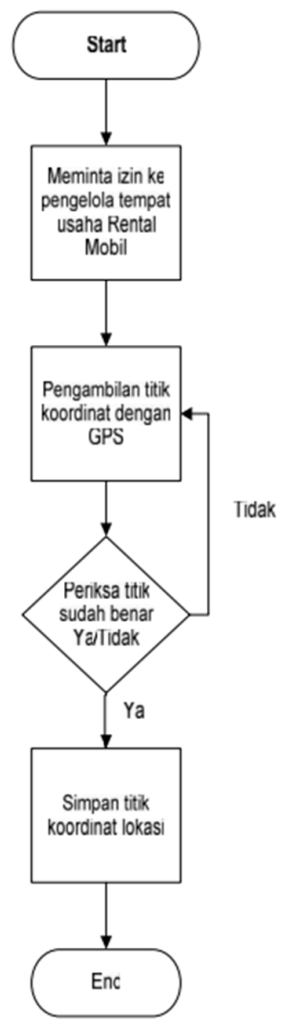

Gambar 2. Flowchart Pengambilan Titik Koordinat

III. HASIL

A. Tampilan WebGIS

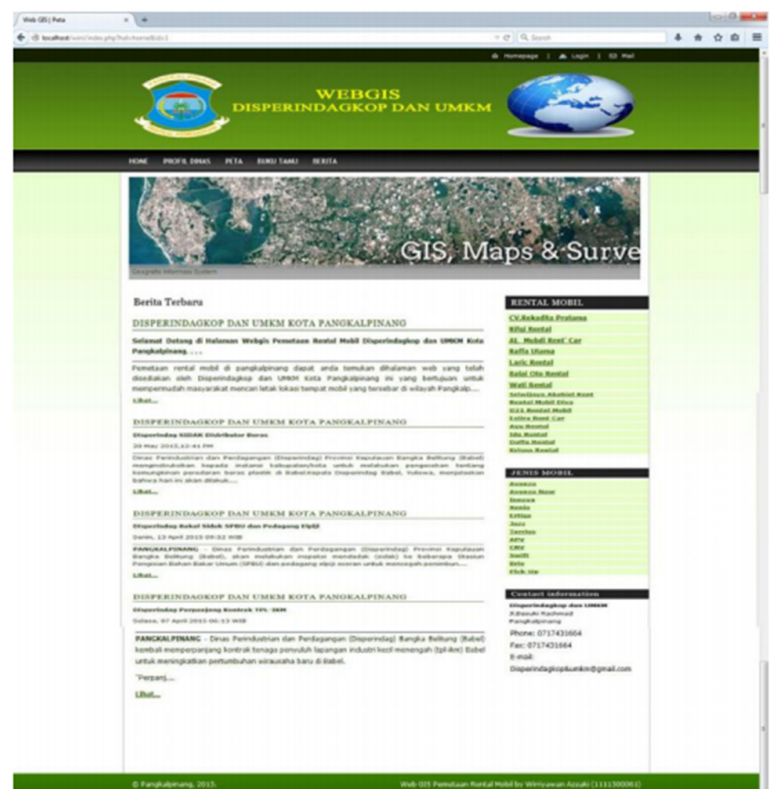

Gambar 3. Tampilan WebGIS 
B. Tampilan Titik Pemetaan Semua Legenda di Aktifkan

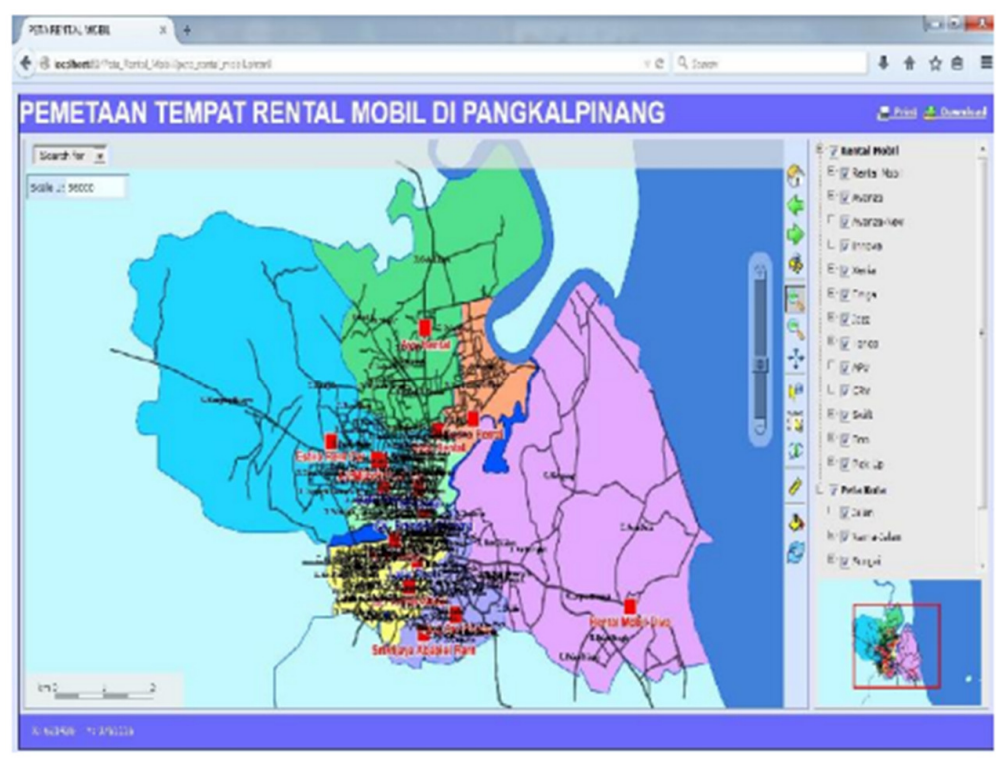

Gambar 4. Tampilan Titik Pemetaan Semua Legent di Aktifkan

C. Penggunaan Tool Search For

Penggunaan ini untuk mempermudah mencari informasi mengenai titik lokasi rental mobil

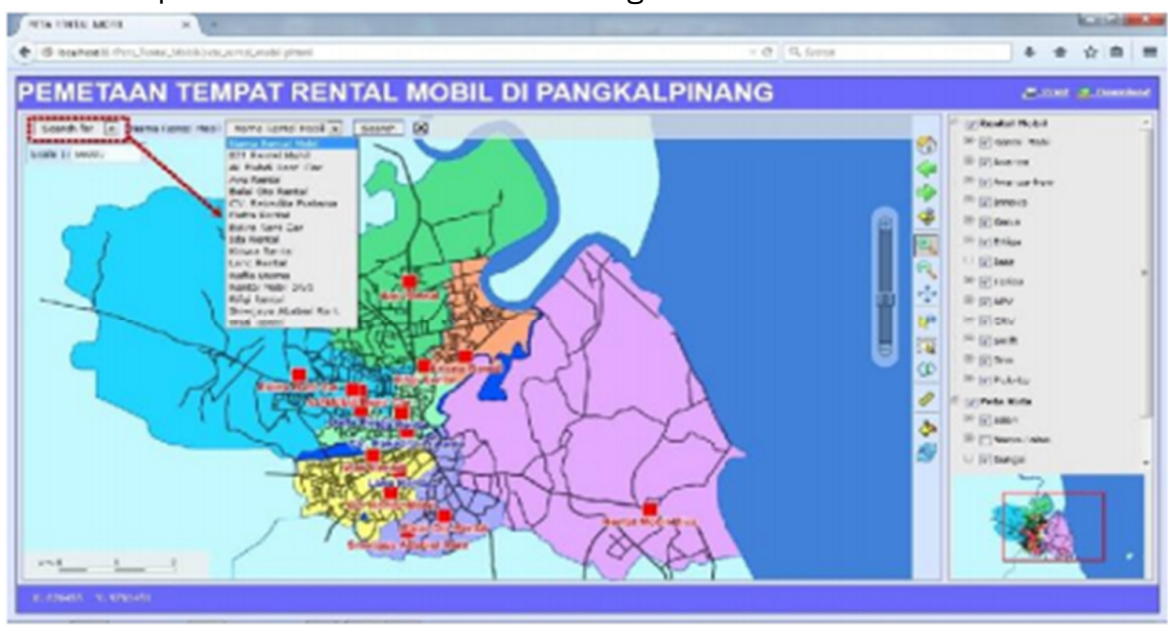

Gambar 5. Penggunaan Tool Search For 
D. Hasil dari Tool Search For

Hasil penggunaan tool ini berfungsi mencari informasi dari lokasi tempat rental mobil

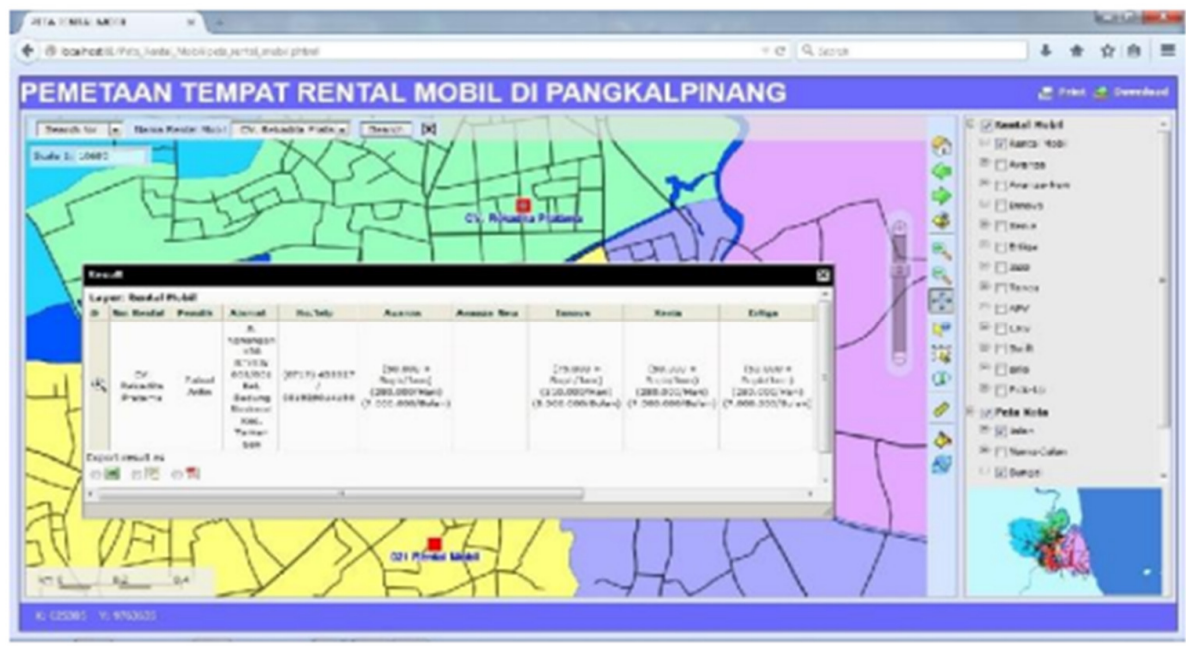

Gambar 6. Hasil dari Tool Search For

\section{KESIMPULAN}

Berdasarkan penelitian yang telah dilakukan penulis mengenai Rancangan Aplikasi Sistem Informasi Geografis Lokasi tempat Penyewaan Mobil Daerah Kota Pangkalpinang Berbasis Web, yang dapat membantu Dinas Perindustrian, Perdagangan, Koperasi dan Usaha Mikro Kecil Menengah (Disperindagkop dan UMKM) dalam menginformasikan tempat penyewaan mobil kepada masyarakat secara efektif dan efisien, kemudian dapat diambil kesimpulan bahwa :

1) Penelitian ini menghasilkan sebuah sistem informasi geografis berbasis web yang dapat menampilkan data berupa peta wilayah Pangkalpinang, serta dapat melakukan penyimpanan data.

2) Informasi Tempat Penyewaan mobil yang dicari dapat diakses melalui WebGis selama 24 jam.

3) Terdapat fasilitas download pada aplikasi Pmapper, sehingga dapat menyimpan informasi peta tersebut.

\section{REFERENSI}

[1] Akmal, Galih Dwi Nisa, “Membangun Sistem Informasi Geografis Pemetaan Perguruan Tinggi Di DIY Berbasis Web”, Yogyakarta: STMIK AMIKOM 2011.

[2] A. S. , Rosa dan M. Shalahuddin, “Rekayasa Perangkat Lunak Terstruktur dan Berorientasi Objek”, Bandung: Informatika, 2013.

[3] FK Sibero Alexander, Kitab Suci Web Programming, Yogyakarta: Mediakom, 2012.

[4] Indarto, "Sistem Informasi Geografis", Yogyakarta: Graha IImu, 2013.

[5] Komputer, Wahana, "Adobe Dreamweaver CS6", Yogyakarta: CV Andi Offset, 2013.

[6] Widjaya, Iwan Kurniawan, “Manajemen Proyek Teknologi Informasi”, Yogyakarta: Graha IImu, 2013.

[7] Kusrianto, Adi, “Panduan Lengkap Memakai Microsoft Office Project 2003”, Jakarta: PT Elex Media Komputindo. 2005.

[8] L. Ramadona, Aditya dan Hari Kusnanto, “Open Source GIS (Aplikasi Quantum GIS Untuk Sistem Informasi Lingkungan)", Yogyakarta: BPFE, 2012.

[9] M. Hasan Iqbal, "Pokok-Pokok Materi Metodologi Penelitian dan Aplikasinya”, jakarata: Ghalia indonesia, 2005.

[10] Sarwono, Jonathan, “Metode Riset Online: Teori, Praktik, dan Pembuatan Aplikasi (Menggunakan HTML, PHP, dan CSS)", Jakarta: PT Elex Media Komputindo, 2012.

[11] Sukwardjono, dkk, "Fakta dan konsep geografi”, Jakarta: Interplus, 2007.

[12] Sutabri, Tata, “Analisis Sistem Informasi”, Jakarta: penerbit andi, 2012.

[13] Taufik, Rahmat, “Sistem Informasi Manajemen (Konsep Dasar, analisis dan Metode Pengembangan)”, Yogyakarta: Graha IImu, 2013.

[14] Utoyo, Bambang, “Geografi: Membuka Cakrawala Dunia”, Bandung: PT. Setia Purna Inves, 2007.

[15] Wahyono Teguh, “36 Jam Belajar Komputer Pemrograman Web Dinamis Dengan PHP, Jakarta: PT. Elek Media Komputindo”, 2005.

[16] Yuhefizar, “10 Jam Menguasai Internet Teknologi dan Aplikasinya, Jakarta: PT.Elex Media Komputindo”, 2008.

[17] Manongga, Danny dkk. Jurnal "Sistem Informasi Geografis untuk Perjalanan Wisata di Kota Semarang”. Fakultas Teknik Informatika Universitas Kristen Satya Wacana.

[18] Priyanto, Eko. Prosiding: Perancangan Sistem Informasi Geografis (SIG) Berbasis Web untuk Penyediaan Informasi Fasilitas dan Personalia di Universitas Lampung. Prosiding Semirata FMIPA Universitas Lampung. 2013. 